\title{
Duckweed (Lemna minor L.) Successfully Accumulates Selenium from Selenium-Impacted Water
}

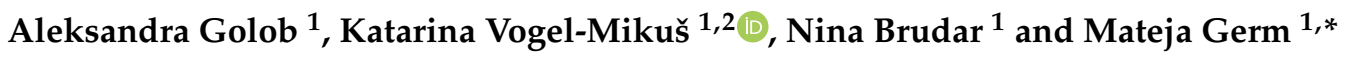 \\ 1 Biotechnical Faculty, University of Ljubljana, SI-1000 Ljubljana, Slovenia; aleksandra.golob@bf.uni-lj.si (A.G.); \\ katarina.vogelmikus@bf.uni-lj.si (K.V.-M.); nina.brudar@gmail.com (N.B.) \\ 2 Department of Low and Medium Energy Physics (F2), Jožef Stefan Institute, SI-1000 Ljubljana, Slovenia \\ * Correspondence: mateja.germ@bf.uni-lj.si; Tel.: +386-13203334
}

check for

updates

Citation: Golob, A.; Vogel-Mikuš, K.; Brudar, N.; Germ, M. Duckweed

(Lemna minor L.) Successfully

Accumulates Selenium from

Selenium-Impacted Water.

Sustainability 2021, 13, 13423. https://

doi.org/10.3390/su132313423

Academic Editors: Ludmiła

Polechońska and Małgorzata Dambiec

Received: 15 October 2021

Accepted: 2 December 2021

Published: 3 December 2021

Publisher's Note: MDPI stays neutral with regard to jurisdictional claims in published maps and institutional affiliations.

\begin{abstract}
The absorption of selenium (Se) from water by Lemna minor L. and the influence of different concentrations and forms of Se on its biochemical and morphological characteristics were studied. Plants were exposed to various concentrations of Se: $1 \mathrm{mg} \mathrm{Se} \mathrm{L}{ }^{-1}, 2 \mathrm{mg} \mathrm{Se} \mathrm{L}^{-1}$ and $5 \mathrm{mg} \mathrm{Se} \mathrm{L}^{-1}$ in

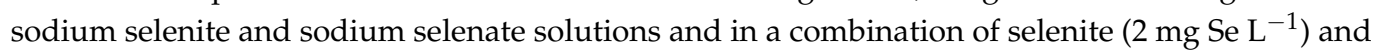
selenate $\left(2 \mathrm{mg} \mathrm{Se} \mathrm{L}^{-1}\right)$. When the Se was added in the form of selenate, plants accumulated higher amounts of Se compared to plants exposed to selenite. Comparisons of the combined addition of selenite and selenate $\left(2+2 \mathrm{mg} \mathrm{Se} \mathrm{L}^{-1}\right)$ with their individual applications $\left(2\right.$ and $\left.5 \mathrm{mg} \mathrm{Se} \mathrm{L}^{-1}\right)$ showed that for the combination, the L. minor fronds accumulated more Se than in selenite alone. Plants exposed to any of the concentrations of sodium selenate or sodium selenite, or the combination of selenite and selenate, showed inferior physiological performances, and lower concentrations of photosynthetic pigments, compared to control plants. Consequently, growth was also suppressed under the stress conditions caused by higher concentrations of Se in any form. The efficient absorption of Se from the water by L. minor indicates the potential use of this species in phytoremediation processes for waters polluted with Se.
\end{abstract}

Keywords: Lemna minor L.; selenite; selenate; biochemical characteristics; accumulation of selenium; phytoremediation

\section{Introduction}

Selenium (Se) is a trace element and an essential microelement for humans, animals and microorganisms [1], whereas this has not been recognized for plants [2]. Se can have positive or negative effects on plant growth, depending on its concentrations and chemical forms, and on the plant physiological and phenological phases [3]. The positive effects on plants are that Se can alleviate the effects of oxidative stress due to strong light intensities [4], low temperatures [5], high temperatures, salts, metals, UV radiation and drought [6-8]. The negative effects of Se can be reflected in decreased growth and development, and early senescence of plants [9].

Pollution of soils and waters by various trace elements has resulted in severe environmental problems, with potential consequences on agriculture and human health. On the other hand, some of these elements are essential micronutrients that are needed for the correct functioning of metabolism and the essential structural and catalytic components of proteins and enzymes, and also as cofactors necessary for normal growth and development [10].

Over a billion people are affected by water pollution issues worldwide, also due to increased amounts of Se, especially in developing countries [11]. Significant sources of Se in the environment can be either lithogenic [12] or anthropogenic, e.g., from mining and agriculture activities [13], residues from fossil fuel thermoelectric power plants and oil refineries, and metal ores $[14,15]$. Se is released into aquatic environments in its inorganic forms, as selenite $\left(\mathrm{SeO}_{3}{ }^{2-}\right)$ and selenate $\left(\mathrm{SeO}_{4}{ }^{2-}\right)$, from both natural and anthropogenic 
sources [16]. Se can enter aquatic food webs and have a detrimental impact on the whole aquatic biota. Thus, there is a significant demand for purification of Se-contaminated waters in certain areas [17].

Macrophytes provide an essential habitat and shelter for many forms of aquatic life, and affect the physical and chemical quality of water, including the light intensity, temperature, $\mathrm{pH}$, hardness and dissolved oxygen [18]. Floating aquatic plants from the genus Lemna (duckweed) are commonly used in toxicity tests due to their small size, rapid growth rate, and structural simplicity [18]. Duckweed fronds are only a few cells in thickness, and consist of spongy mesophyll with large air spaces that make the fronds buoyant; duckweed are either rootless or bear one to several simple roots on the underside [19]. Under ideal conditions, duckweed plants can double their mass in $<2$ days, which is faster than for any other higher plant [20].

Duckweed can take up nutrients, such as nitrogen and phosphorus, and many toxic substances from contaminated waters. They can also remove or accumulate metals, radionuclides and other pollutants in their tissues [21]. For example, duckweed is effective for the removal of Se at increasing concentrations (1-50 ppm). The effectiveness of Se removal from water can be over 99\% [22]. The duckweed species Lemna minor (common duckweed) was selected here for its rapid vegetative reproduction and inherent bioaccumulation of Se [23].

The representatives of genus Lemna are valuable for forage and food, and are medicinal plants; they can also be used as an energy source for biofuel production. These plants contain essential amino acids, aspartic and glutamic acids, and carbohydrates, and vitamins of groups A, B and E [24]. Plant growth is stimulated or inhibited by toxicants entering the aquatic ecosystem, and both effects can negatively impact on ecosystem functionality [18]. After absorption by duckweed, toxic substances can have a deleterious impact on the biochemical characteristics of the duckweed, which represents an indicator of the presence of toxic substances in waters [19]. Kastratović et al. [25] proposed L. minor as a bioindicator, to estimate the presence of metals in the surrounding environment, because it tolerates considerable amounts of metals without negative effects on its growth and development. Furthermore, Li et al. [26] claimed that L. minor can be used as a bioindicator of water pollution, as it is very sensitive to silver contamination. The use of biota for bioindication is important, because biota assess the cumulative impact of both chemical pollutants and habitat alterations over time.

Information about the up-take of different forms of Se from aquatic media by macrophytes is limited $[22,23,27-31]$. Therefore, the aim of the present study was to define the response of L. minor to different concentrations and forms of Se and to investigate its absorption of Se from contaminated environments, along with its possible use in phytoremediation processes. Different physiological and biochemical characteristics of duckweed plants were evaluated, together with the Se concentrations in the plants.

\section{Materials and Methods}

\subsection{Common Duckweed Cultivation and Exposure}

Lemna minor was collected from a pond in Ljubljana $\left(46.051206^{\circ} \mathrm{N}, 14.457946^{\circ} \mathrm{E}\right)$. In the laboratory, before transfer to the growth chamber, the plants were immersed in $0.01 \mathrm{M}$ sodium hypochlorite ( $\mathrm{NaOCl}$; Šampionka d.o.o., Koper, Slovenia) solution for $30 \mathrm{~s}$, and rinsed with tap water. After 2 weeks of acclimatisation in nutrient solution without added Se (Table 1), plants were exposed to different concentrations of Se $\left(1,2,5 \mathrm{mg} \mathrm{Se} \mathrm{L}^{-1}\right)$ in the form of sodium selenite $\left(\mathrm{Na}_{2} \mathrm{SeO}_{3}\right.$; Sigma-Aldrich, St. Louis, MO, USA) and sodium selenate $\left(\mathrm{Na}_{2} \mathrm{SeO}_{4}\right.$; Sigma-Aldrich) in crystallising dishes filled with $250 \mathrm{~mL}$ Steinberg growth medium (ISO/CD 20079) (Table 1). Plants were also exposed to a combination of

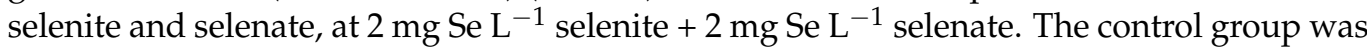
grown in growth medium without addition of Se. The experiments were conducted as four independent trials, with five replicates per exposure and for the controls. Experimental 
plants were kept in the growth chamber at $22 \pm 1{ }^{\circ} \mathrm{C}$, under cold white fluorescent light (intensity, $160 \mu \mathrm{M} \mathrm{m}^{-2} \mathrm{~s}^{-1} \mathrm{PAR}$ ), and with a light/dark cycle of $18 \mathrm{~h}: 6 \mathrm{~h}$.

Table 1. Composition of Steinberg growth medium (ISO/CD 20079).

\begin{tabular}{cc}
\hline Macroelements & $\mathbf{m g ~ L}^{\mathbf{- 1}}$ \\
\hline $\mathrm{KNO}_{3}$ & 350.0 \\
$\mathrm{Ca}\left(\mathrm{NO}_{3}\right)_{2} \cdot 4 \mathrm{H}_{2} \mathrm{O}$ & 295.0 \\
$\mathrm{KH}_{2} \mathrm{PO}_{4}$ & 90.0 \\
$\mathrm{~K}_{2} \mathrm{HPO}_{4}$ & 12.6 \\
$\mathrm{MgSO}_{4} \cdot 7 \mathrm{H}_{2} \mathrm{O}$ & 100.0 \\
\hline Macroelements & $\boldsymbol{\mu g ~ L}^{-\mathbf{1}}$ \\
$\mathrm{H}_{3} \mathrm{BO}_{3}$ & 120.0 \\
$\mathrm{ZnSO}_{4} \cdot 7 \mathrm{H}_{2} \mathrm{O}$ & 180.0 \\
$\mathrm{Na}_{2} \mathrm{MoO}_{4} \cdot 2 \mathrm{H}_{2} \mathrm{O}$ & 44.0 \\
$\mathrm{MnCl}_{2} \cdot 4 \mathrm{H}_{2} \mathrm{O}$ & 180.0 \\
$\mathrm{FeCl}_{3} \cdot 6 \mathrm{H}_{2} \mathrm{O}$ & 760.0 \\
$\mathrm{EDTA}$ & 1500.0 \\
\hline
\end{tabular}

In the first trial, the initial number of fronds was 12. In the second and third trials, the number of fronds was increased to 16. In the fourth trial, however, each crystallising dish was filled with plant material for up to half of its area, to ensure enough plant material to perform the analyses of Se content. For the fourth trial, new fresh plant material was collected because the plants had begun to decay, and were no longer as vital as in the first three trials. All of the crystallising dishes were covered with transparent plastic film (semi-permeable, to allow exchange of all gases), thus reducing water evaporation from the medium and preventing any impurities from entering the growth medium. Light penetration to the growth medium was not restricted. The crystallising dishes were placed in a growth chamber on a dark background, and they were randomly moved around on a daily basis. The stock culture was kept in a 10-L plastic container with Steinberg growth medium, in another growth chamber at $22 \pm 1{ }^{\circ} \mathrm{C}$, again under cold white fluorescent light (intensity, $160 \mu \mathrm{M} \mathrm{m}^{-2} \mathrm{~s}^{-1} \mathrm{PAR}$ ), with a light/dark cycle of $18 \mathrm{~h}: 6 \mathrm{~h}$.

\subsection{Physiological Analyses}

Terminal electron transport system (ETS) activity was measured according to the assay originally proposed by Packard [32], and modified by Kenner and Ahmed [33]. A known fresh weight of fronds was crushed in a mortar in $4 \mathrm{~mL}$ final volume of ice-cold $0.1 \mathrm{M}$ sodium phosphate buffer ( $\mathrm{pH} 8.4$ ) containing $0.15 \%(w / v)$ polyvinyl pyrrolidone, $75 \mu \mathrm{M} \mathrm{MgSO}_{4}$, and $0.2 \%(v / v)$ Triton-X-100, followed by an ultrasonic homogeniser (4710; Cole-Parmer, Vernon Hills, IL, USA) for $20 \mathrm{~s}$ at $40 \mathrm{~W}$. The homogenates were centrifuged in an ultracentrifuge for $4 \mathrm{~min}$ at $0{ }^{\circ} \mathrm{C}$ at 10,000 rpm (2K15; Sigma). Within $10 \mathrm{~min}, 0.5 \mathrm{~mL}$ of supernatant (in triplicate) was incubated in $1.5 \mathrm{~mL}$ substrate solution ( $0.1 \mathrm{M}$ sodium phosphate buffer, $\mathrm{pH}$ 8.4, $1.7 \mathrm{mM}$ NADH, $0.25 \mathrm{mM}$ NADPH, $0.2 \%$ [ $v / v]$ Triton-X-100) and $0.5 \mathrm{~mL}$ INT (20 mg 2-p-iodo-phenyl 3-p-nitrophenyl 5-phenyl tetrazolium chloride in $10 \mathrm{~mL}$ of bidistilled water), for $40 \mathrm{~min}$ at $20^{\circ} \mathrm{C}$. Formazan production was determined spectrophotometrically by measuring absorption at $490 \mathrm{~nm}$ against the blank. ETS activity was measured as the rate of tetrazolium dye reduction, and was converted to equivalent oxygen as proposed by Kenner and Ahmed [33].

Photochemical efficiency was measured as the potential quantum yield of photosystem II (PS II), determined by measurement of the chlorophyll a fluorescence [34]. Measurements of minimal $\left(\mathrm{F}_{0}\right)$ and maximal $\left(\mathrm{F}_{\mathrm{m}}\right)$ chlorophyll fluorescence were taken under conditions of darkness for $30 \mathrm{~min}$, using special aluminium clips. Fluorescence was excited with a saturating beam of 'white light' (photosynthetic photon flux density, $8000 \mu \mathrm{mol} \mathrm{m}{ }^{-2} \mathrm{~s}^{-1}$, $0.8 \mathrm{~s})$. The difference between $\mathrm{F}_{\mathrm{m}}$ and $\mathrm{F}_{0}$ is called the variable fluorescence $\left(\mathrm{F}_{\mathrm{v}}\right)$. 


\subsection{Biochemical Analyses}

The contents of photosynthetic pigments were determined according to Lichtenthaler and Buschmann [35]. Fresh common duckweed fronds were weighed and then homogenised and extracted in $5 \mathrm{~mL}$ acetone $(100 \%, v / v)$ and centrifuged. Absorbances at wavelengths of $470 \mathrm{~nm}, 645 \mathrm{~nm}$ and $662 \mathrm{~nm}$ were measured spectrophotometrically. Calculation of chlorophyll contents was according to Lichtenthaler and Buschmann [36].

The contents of anthocyanins were measured according to Drumm and Mohr [37]. Fresh common duckweed fronds were weighted and then homogenised and extracted in $10 \mathrm{~mL}$ methanol: $\mathrm{HCl}(37 \% ; 99: 1, v / v)$. Absorbances at a wavelength of $530 \mathrm{~nm}$ were measured. Calculation of anthocyanin contents was according to Drumm and Mohr [37].

The contents of UV absorbing compounds were determined and calculated according to Caldwell [38]. Initially, fresh common duckweed fronds were weighed, ground in a mortar, and then extracted into $5 \mathrm{~mL}$ extraction medium (methanol: distilled water: $\mathrm{HCl}$ (37\%; 79: 20: 1, v/v). They were then incubated for $20 \mathrm{~min}$ and centrifuged at $4000 \mathrm{rpm}$. Absorbances were measured at wavelengths from $280 \mathrm{~nm}$ to $400 \mathrm{~nm}$.

\subsection{Growth Parameters}

Growth characteristics were determined by counting the fronds at the end of each trial. Visual signs of possible toxicity (e.g., discoloration of the fronds) were monitored by counting green, yellow and brown fronds.

\subsection{Concentrations of Selenium, Calcium and Potassium}

The Se, calcium (Ca) and potassium (K) concentrations in the plant material were determined by X-ray fluorescence (XRF) spectrometry. Plant material was lyophilised (Alpha Christ) for 3 days, ground in a mortar with liquid nitrogen, and pressed into pellets (diameter, $2.5 \mathrm{~cm}$ ) using a pellet die and a hydraulic press. The pellets were weighed and measured using Cd-109 radioisotope source excitation (Eckert \& Ziegler, Valencia, CA, USA). Characteristic X-ray fluorescence lines were detected by a silicon drift diode (Amptek, Bedford, MA, USA) with an energy resolution of $140 \mathrm{eV}$ at $5.9 \mathrm{keV}$. The XRF spectra were fitted and quantified according to Kump et al. [39]. The XRF analysis was validated using various standard reference materials [40]: wheat flour (certified value, $1.14 \pm 0.1 \mu \mathrm{g} / \mathrm{g}$; measured value, $1.2 \pm 0.3 \mu \mathrm{g} / \mathrm{g}$ ) and oyster tissue (certified value, $2.06 \pm 0.15 \mu \mathrm{g} / \mathrm{g}$; measured value, $2.1 \pm 0.4 \mu \mathrm{g} / \mathrm{g})$.

The bioconcentration factor (BCF) was calculated following Zayed et al. [41]:

$$
\mathrm{BCF}=\frac{\text { Se concentration in plants }\left(\mu \mathrm{g} \mathrm{g}^{-1}\right)}{\text { Se concentration in medium }\left(\mathrm{mg} \mathrm{L}^{-1}\right)}
$$

\subsection{Statistical Analysis}

The normal distribution of the data was tested using Shapiro-Wilk tests. Homogeneity of variance from the means was assessed using Levene's tests. Differences in the observed parameters between the control plants and the plants under the different treatments were evaluated using one-way ANOVA, followed by Duncan post hoc multiple comparison tests. Significance was accepted at $p<0.05$. To determine possible relationships between the contents of the elements in common duckweed and the measured biochemical, physiological and growth parameters, Spearman's rank correlation analysis was performed. The SPSS Statistics software, version 25.0 (IBM), was used for these calculations.

Redundancy analysis was used to determine whether the variations in biochemical, physiological and growth parameters were related to the elemental composition of the common duckweed (i.e., the concentrations of $\mathrm{Se}, \mathrm{Ca}, \mathrm{K}$ ). Monte Carlo permutation tests with 999 permutations were used to test the significance of the effects. The level for significance was accepted at $p<0.05$. All of the variables used in the analysis were standardised. These analyses were performed using the Canoco software for Windows $5.0[42]$. 


\section{Results}

The contents of total chlorophyll $(\mathrm{a}+\mathrm{b})$, carotenoids, anthocyanins and UV absorbing substances, and the photochemical efficiency of PS II and ETS activity were the highest in the control samples compared across to all of the treatments. However, the differences were not statistically significant for all of the treatments in all of the trials. ETS activity, photochemical efficiency, and concentrations of total chlorophyll, anthocyanins, carotenoids and UV absorbing substances in L. minor decreased with increasing concentrations of selenite and selenate in the growth media (Figures 1-6).

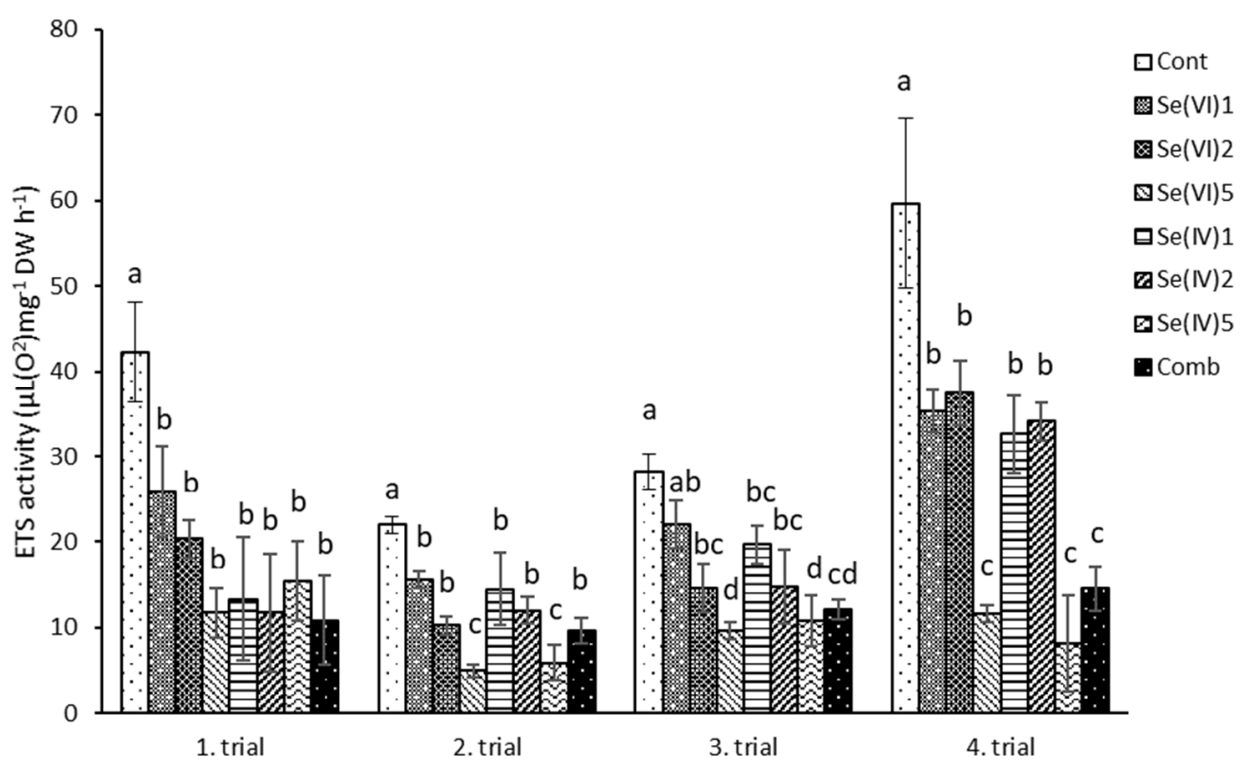

Figure 1. Electron transport system activity in mitochondria in control and Se-treated L. minor from all four trials. Data are means $\pm S E(N=5)$. Data indicated with different letters were significantly different $(p<0.05$; within each trial). Legend: DW, dry weight; Cont, control; Se(IV)1, 2, 5, selenite at 1, 2, $5 \mathrm{mg} \mathrm{Se} \mathrm{L}^{-1}$; $\mathrm{Se}(\mathrm{VI}) 1,2,5$, selenate at 1, 2, $5 \mathrm{mg} \mathrm{Se} \mathrm{L}^{-1}$; Comb, selenite and selenate at $4 \mathrm{mg} \mathrm{Se} \mathrm{L}^{-1}$ (i.e., $2+2$ ).

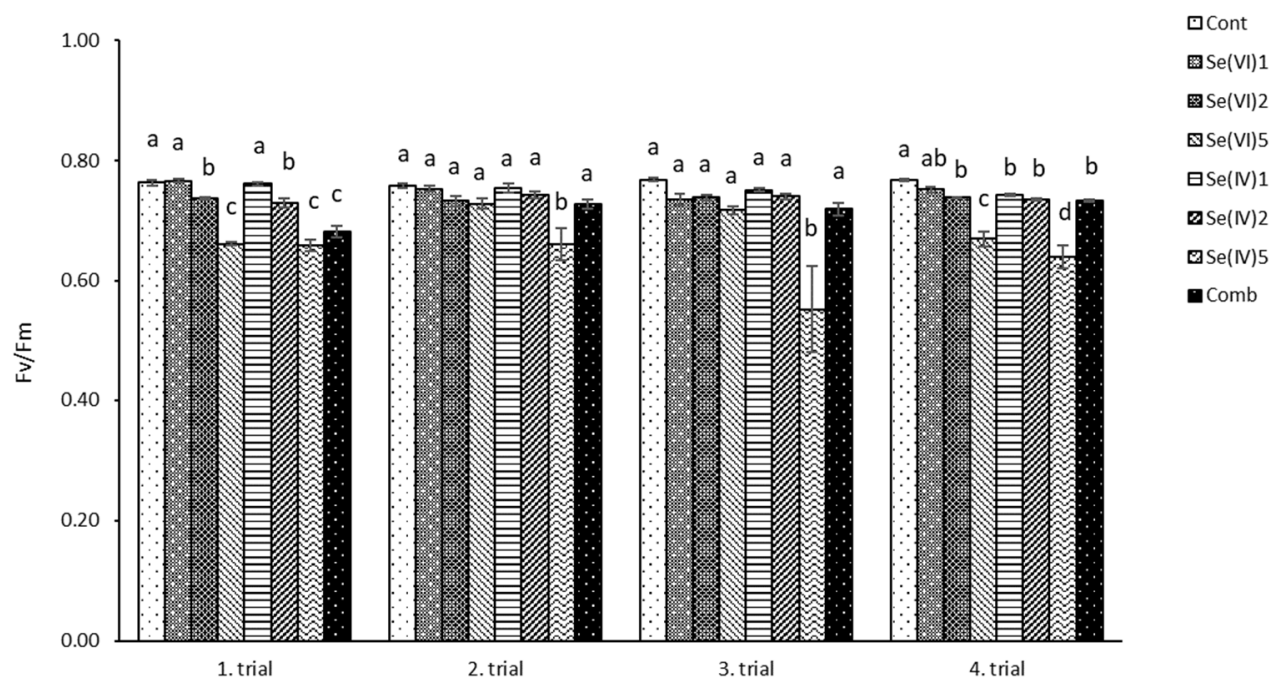

Figure 2. Potential photochemical efficiency of photosystem II in control and Se-treated L. minor from all four trials. Data are means $\pm \mathrm{SE}(\mathrm{N}=5)$. Data indicated with different letters were significantly different $\left(p<0.05\right.$; within each trial). Legend: Cont, control; Se(IV)1, 2, 5, selenite at 1, 2, $5 \mathrm{mg} \mathrm{Se} \mathrm{L}^{-1}$; $\mathrm{Se}(\mathrm{VI}) 1,2,5$, selenate at 1, 2, $5 \mathrm{mg} \mathrm{Se} \mathrm{L}^{-1}$; Comb, selenite and selenate at $4 \mathrm{mg} \mathrm{Se} \mathrm{L}^{-1}$ (i.e., $2+2$ ). 


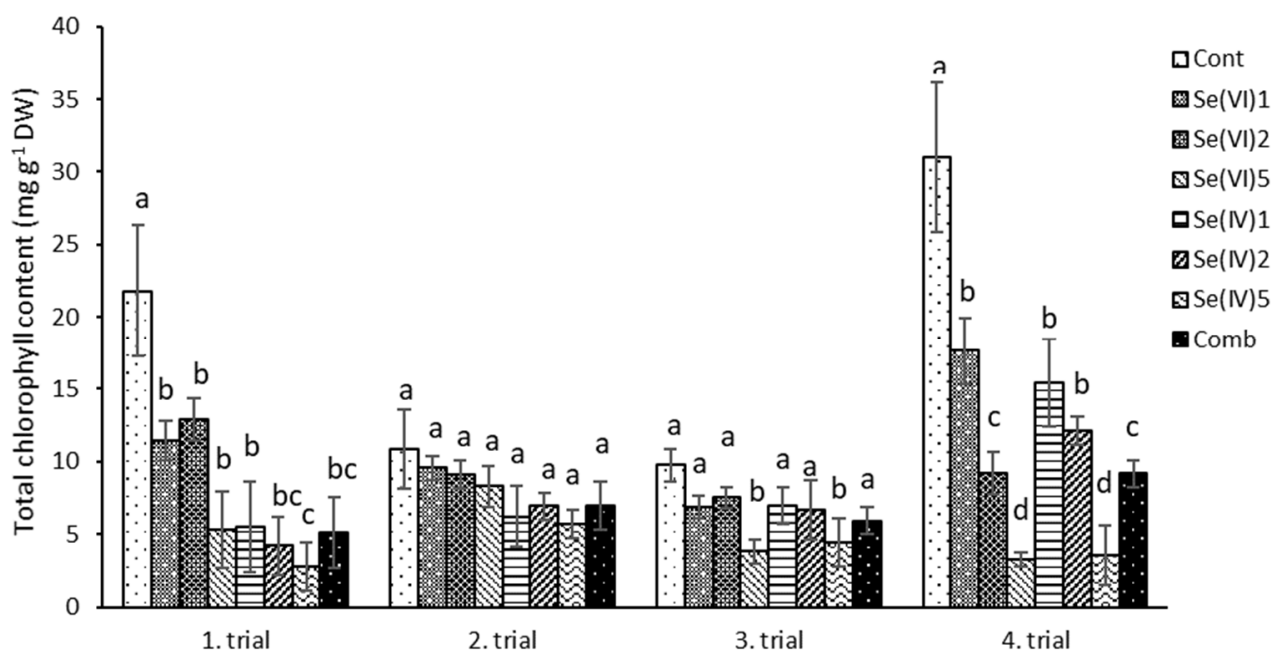

Figure 3. Total chlorophyll contents in control and Se-treated L. minor from all four trials. Data are means $\pm S E(N=5)$. Data indicated with different letters were significantly different $(p<0.05$; within each trail). Legend: DW, dry weight; Cont, control; Se(IV)1, 2, 5, selenite at 1, 2, 5 mg Se L ${ }^{-1}$; Se(VI)1,

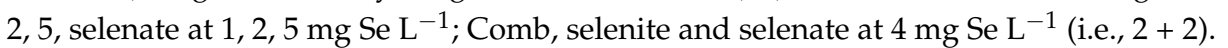

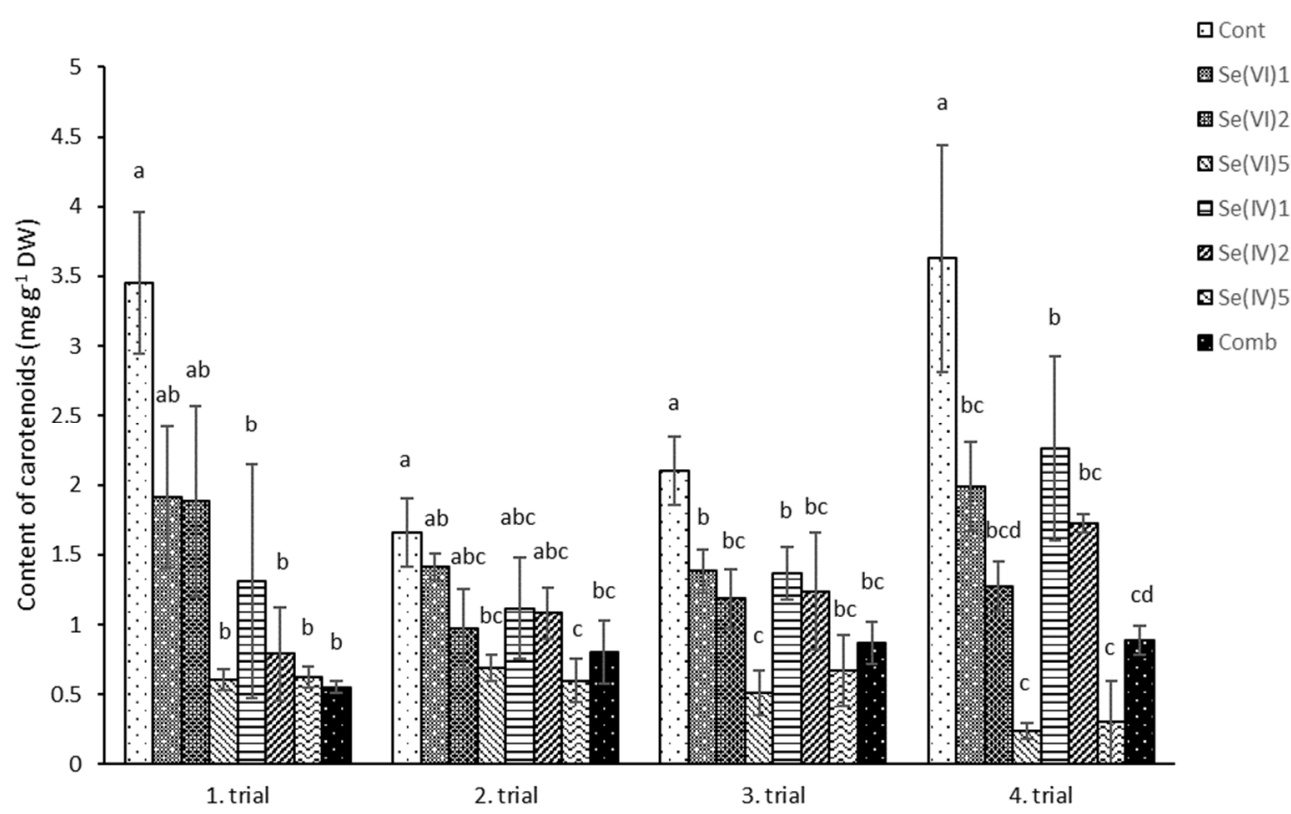

Figure 4. Total carotenoids contents in control and Se-treated L. minor from all four trials. Data are means $\pm S E(N=5)$. Data indicated with different letters were significantly different $(p<0.05$; within each trial). Legend: DW, dry weight; Cont, control; Se(IV)1, 2, 5, selenite at 1, 2, $5 \mathrm{mg} \mathrm{Se} \mathrm{L}^{-1}$; Se(VI)1,

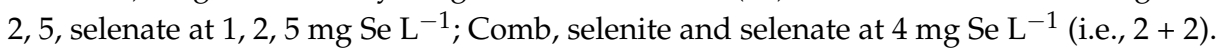

\subsection{Physiological Measurements}

The ETS activity of L. minor decreased with increasing concentration of Se, irrespectively of the form of Se. In the fourth trial, L. minor grown in media with selenite and selenate at $5 \mathrm{mg} \mathrm{Se} \mathrm{L}^{-1}$ and the combination of selenite and selenate had significantly lower ETS activity than L. minor grown in media with lower concentrations of Se. In the first, second and third trials, the differences between treatments for ETS activities were less pronounced (Figure 1). 


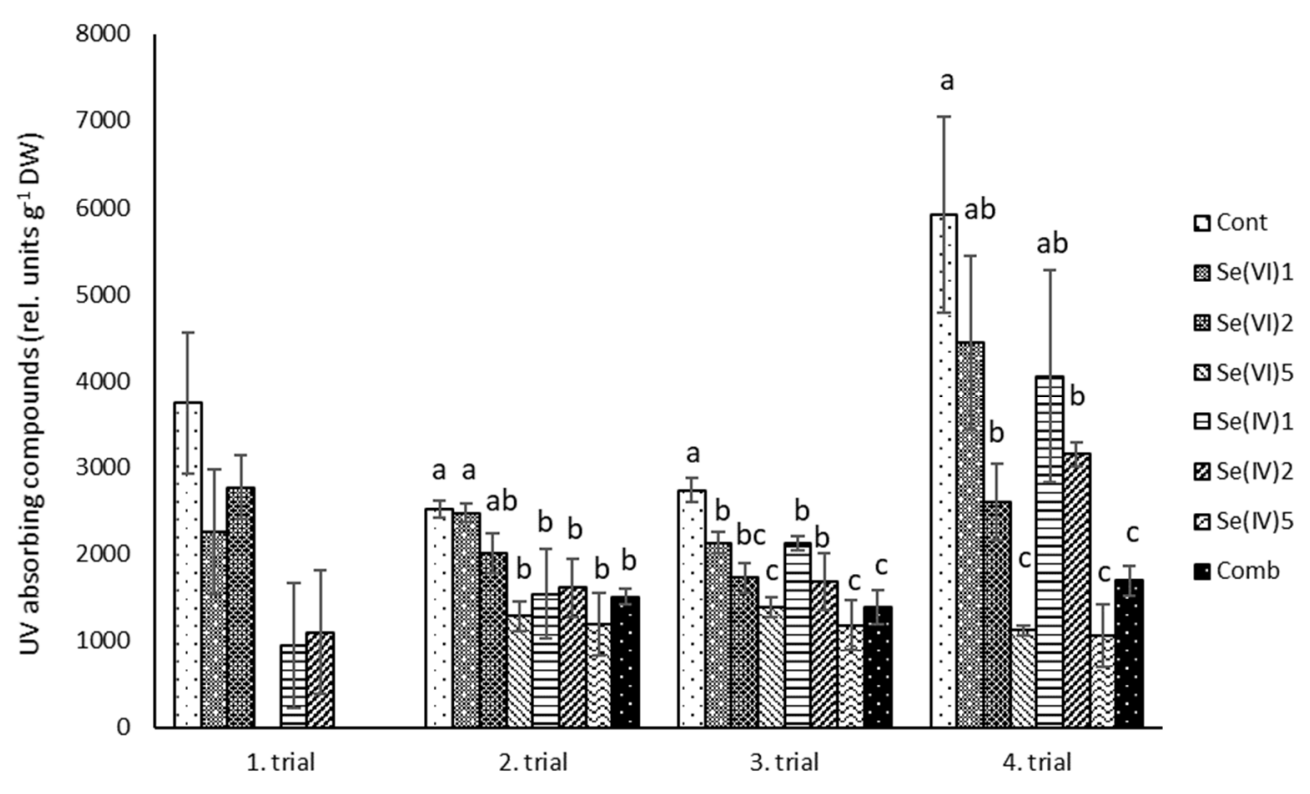

Figure 5. Contents of UV absorbing compounds in control and Se-treated L. minor from all four trials. Data are means $\pm \mathrm{SE}(\mathrm{N}=5)$. Data indicated with different letters were significantly different $(p<0.05$; within each trail). Legend: DW, dry weight; Cont, control; Se(IV)1, 2, 5, selenite at 1, 2, $5 \mathrm{mg} \mathrm{Se} \mathrm{L}{ }^{-1}$; Se(VI)1, 2, 5, selenate at 1, 2, $5 \mathrm{mg} \mathrm{Se} \mathrm{L}^{-1}$; Comb, selenite and selenate at $4 \mathrm{mg} \mathrm{Se} \mathrm{L}^{-1}$ (i.e., $2+2)$.

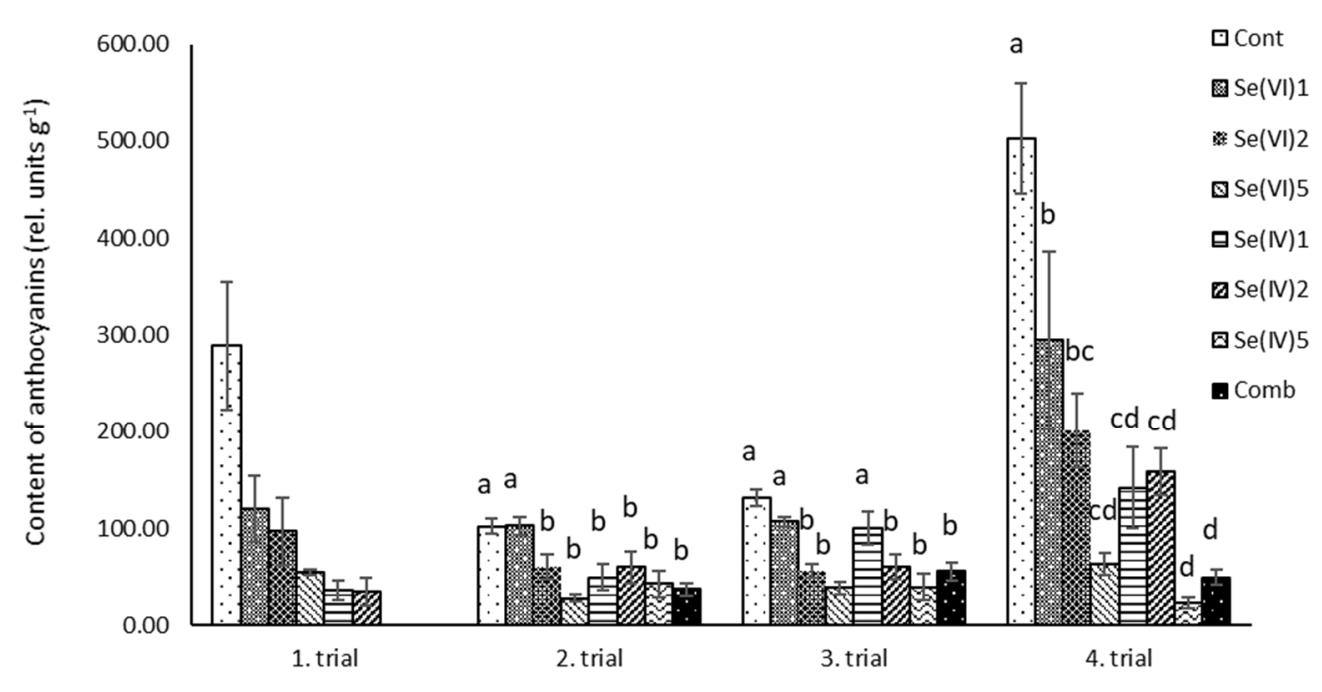

Figure 6. Anthocyanins contents in control and Se-treated L. minor from all four trials. Data are means $\pm \mathrm{SE}(\mathrm{N}=5)$. Data indicated with different letters were significantly different $(p<0.05$; within each trial). Legend: Cont, control; Se(IV)1, 2, 5, selenite at 1, 2, $5 \mathrm{mg} \mathrm{Se} \mathrm{L}^{-1}$; $\mathrm{Se}(\mathrm{VI}) 1,2,5$, selenate at 1 , $2,5 \mathrm{mg} \mathrm{Se} \mathrm{L}^{-1}$; Comb, selenite and selenate at $4 \mathrm{mg} \mathrm{Se} \mathrm{L}^{-1}$ (i.e., $2+2$ ).

In the first and fourth trials, the potential photochemical efficiency of PS II (measured as $\mathrm{Fv} / \mathrm{Fm}$ ) was significantly decreased in L. minor grown in media with selenite and selenate at 2 and $5 \mathrm{mg} \mathrm{Se} \mathrm{L}^{-1}$, compared to the control. In the second and third trials, decreased potential photochemical efficiency of PS II was observed only for plants grown in media with the addition of selenite at $5 \mathrm{mg} \mathrm{Se} \mathrm{L}^{-1}$ (Figure 2).

\subsection{Biochemical Measurements}

The results from the first and fourth trials showed that all of the treatments decreased the total chlorophyll contents in L. minor, compared to the control. The decreases were 


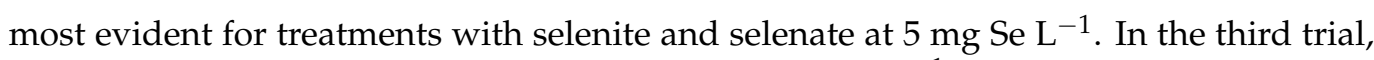
only the treatment with selenite and selenate at $5 \mathrm{mg} \mathrm{Se} \mathrm{L}^{-1}$ significantly decreased the total chlorophyll contents, compared to control. The other treatments from the third trial showed the same trends for total chlorophyll contents as for the first and third trials, but the differences were not statistically significant from the controls. In the second trial, the differences between treatments and control for chlorophyll contents followed the same pattern as in the other trials, although these were not statistically significant (Figure 3).

Lemna minor grown in media with added selenite and selenate at $5 \mathrm{mg} \mathrm{Se} \mathrm{L}^{-1}$ and as the combination had significantly lower carotenoid contents, compared to control plants. In the third and fourth trials, even the lower Se concentrations in the growth media provoked such effects (Figure 4).

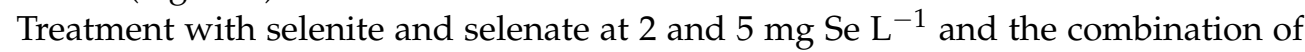
selenite and selenate decreased the content of UV absorbing compounds compared to the controls in the second, third and fourth trials. In the first trial, treatments with selenite and selenate at $5 \mathrm{mg} \mathrm{Se} \mathrm{L}^{-1}$ and the combination of selenite and selenate reduced the number of fronds to such an extent that there was not enough material to analyse the contents of UV absorbing compounds and anthocyanins. However, the results from the other treatments and the control from the first trial showed the same trends for the contents of UV absorbing compound and anthocyanins as in the other trials (Figures 5 and 6).

Treatment with selenite and selenate at 2 and $5 \mathrm{mg} \mathrm{Se} \mathrm{L}^{-1}$ and the combination of selenite and selenate decreased the anthocyanins contents, compared to the controls in the second, third and fourth trials. In the fourth trial, even the treatments with selenite and selenate at $1 \mathrm{mg} \mathrm{Se} \mathrm{L^{-1 }}$ significantly decreased the anthocyanins contents compared to the control (Figure 6).

\subsection{Growth Parameters}

Treatment with selenite and selenate at 2 and $5 \mathrm{mg} \mathrm{Se} \mathrm{L}^{-1}$ and the combination of selenite and selenate inhibited the growth of duckweed, compared to the control. The degree of inhibition increased with increasing concentrations of Se in the growth medium (Table 2).

Table 2. Ratios for the number of duckweed fronds between each treatment and its control after 7 days of growth.

\begin{tabular}{ccccccc}
\hline Treatment & 1. Trial & 2. Trial & 3. Trial & 4. Trial & $\begin{array}{c}\text { Bio-Concentration } \\
\text { Factor }\end{array}$ & $\begin{array}{c}\text { Fronds with } \\
\text { Chlorosis (\%) * }\end{array}$ \\
\hline Cont & $1 \pm 0.042^{\mathrm{a}}$ & $1 \pm 0.028^{\mathrm{a}}$ & $1 \pm 0.031^{\mathrm{a}}$ & $1 \pm 0.007^{\mathrm{a}}$ & & $0.36 \pm 0.09^{\mathrm{d}}$ \\
$\mathrm{Se}(\mathrm{VI}) 1$ & $1.20 \pm 0.042^{\mathrm{a}}$ & $0.94 \pm 0.027^{\mathrm{b}}$ & $0.93 \pm 0.067^{\mathrm{b}}$ & $0.93 \pm 0.011^{\mathrm{b}}$ & $153 \pm 6^{\mathrm{a}}$ & $0.91 \pm 0.11^{\mathrm{d}}$ \\
$\mathrm{Se}(\mathrm{VI}) 2$ & $0.99 \pm 0.065^{\mathrm{a}}$ & $0.78 \pm 0.065^{\mathrm{c}}$ & $0.85 \pm 0.043^{\mathrm{b}}$ & $0,79 \pm 0.004^{\mathrm{c}}$ & $167^{\mathrm{a}}$ & $1.36 \pm 0.12^{\mathrm{c}}$ \\
$\mathrm{Se}(\mathrm{VI}) 5$ & $0.40 \pm 0.036^{\mathrm{c}}$ & $0.50 \pm 0.040^{\mathrm{d}}$ & $0.59 \pm 0.073^{\mathrm{cd}}$ & $0.51 \pm 0.004^{\mathrm{e}}$ & $55^{\mathrm{c}}$ & $2.17 \pm 0.35^{\mathrm{bc}}$ \\
$\mathrm{Se}(\mathrm{IV}) 1$ & $1.08 \pm 0.056^{\mathrm{a}}$ & $0.94 \pm 0.059^{\mathrm{b}}$ & $0.98 \pm 0.081^{\mathrm{ab}}$ & $0.92 \pm 0.023^{\mathrm{b}}$ & $99 \pm 4^{\mathrm{b}}$ & $0.78 \pm 0.13^{\mathrm{d}}$ \\
$\mathrm{Se}(\mathrm{IV}) 2$ & $0.68 \pm 0.040^{\mathrm{b}}$ & $0.68 \pm 0.039^{\mathrm{c}}$ & $0.8 \pm 0.107^{\mathrm{b}}$ & $0.72 \pm 0.007^{\mathrm{d}}$ & $80 \pm 2^{\mathrm{c}}$ & $1.90 \pm 0.28^{\mathrm{c}}$ \\
$\mathrm{Se}(\mathrm{IV}) 5$ & $0.39 \pm 0.014^{\mathrm{c}}$ & $0.48 \pm 0.056^{\mathrm{d}}$ & $0.47 \pm 0.047^{\mathrm{d}}$ & $0.45 \pm 0.002^{\mathrm{f}}$ & $45 \pm 1^{\mathrm{d}}$ & $8.38 \pm 1.66^{\mathrm{a}}$ \\
Comb & $0.49 \pm 0.010^{\mathrm{c}}$ & $0.49 \pm 0.048^{\mathrm{d}}$ & $0.61 \pm 0.033^{\mathrm{c}}$ & $0.51 \pm 0.002^{\mathrm{e}}$ & $66^{\mathrm{c}}$ & $3.65 \pm 0.89^{\mathrm{b}}$ \\
\hline
\end{tabular}

Data are means $\pm \mathrm{SE}(\mathrm{N}=5)$. Data indicated with different letters were significantly different $(p<0.05) .{ }^{*}$ Means of all four trials. Legend: Cont, control; Se(IV)1, 2, 5, selenite at 1, 2, $5 \mathrm{mg} \mathrm{Se} \mathrm{L}^{-1}$; $\mathrm{Se}(\mathrm{VI}) 1,2,5$, selenate at 1, 2, $5 \mathrm{mg} \mathrm{Se} \mathrm{L}^{-1}$; Comb, selenite and selenate at $4 \mathrm{mg} \mathrm{Se} \mathrm{L}^{-1}$ (i.e., $2+2)$.

At $5 \mathrm{mg} \mathrm{Se} \mathrm{L}^{-1}$ in the growth media, the growth of duckweed was reduced by about half, compared to the control. The decline in growth was greater for selenite compared to selenate, but only at $2 \mathrm{mg} \mathrm{Se} \mathrm{L}^{-1}$ or higher. The addition of selenite and selenate at $1 \mathrm{mg} \mathrm{Se} \mathrm{\textrm {L } ^ { - 1 }}$ only had small effects on the growth of the duckweed over 1 week (Table 2, Figure 7). Treatments with selenite and selenate also increased the proportions of the fronds with chlorosis, compared to the controls. These results showed that chlorosis was more prevalent for duckweed to which selenite was added, compared to selenate. The greatest differences in the proportions of fronds with chlorosis between selenite and selenate were

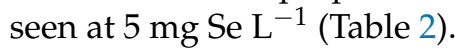




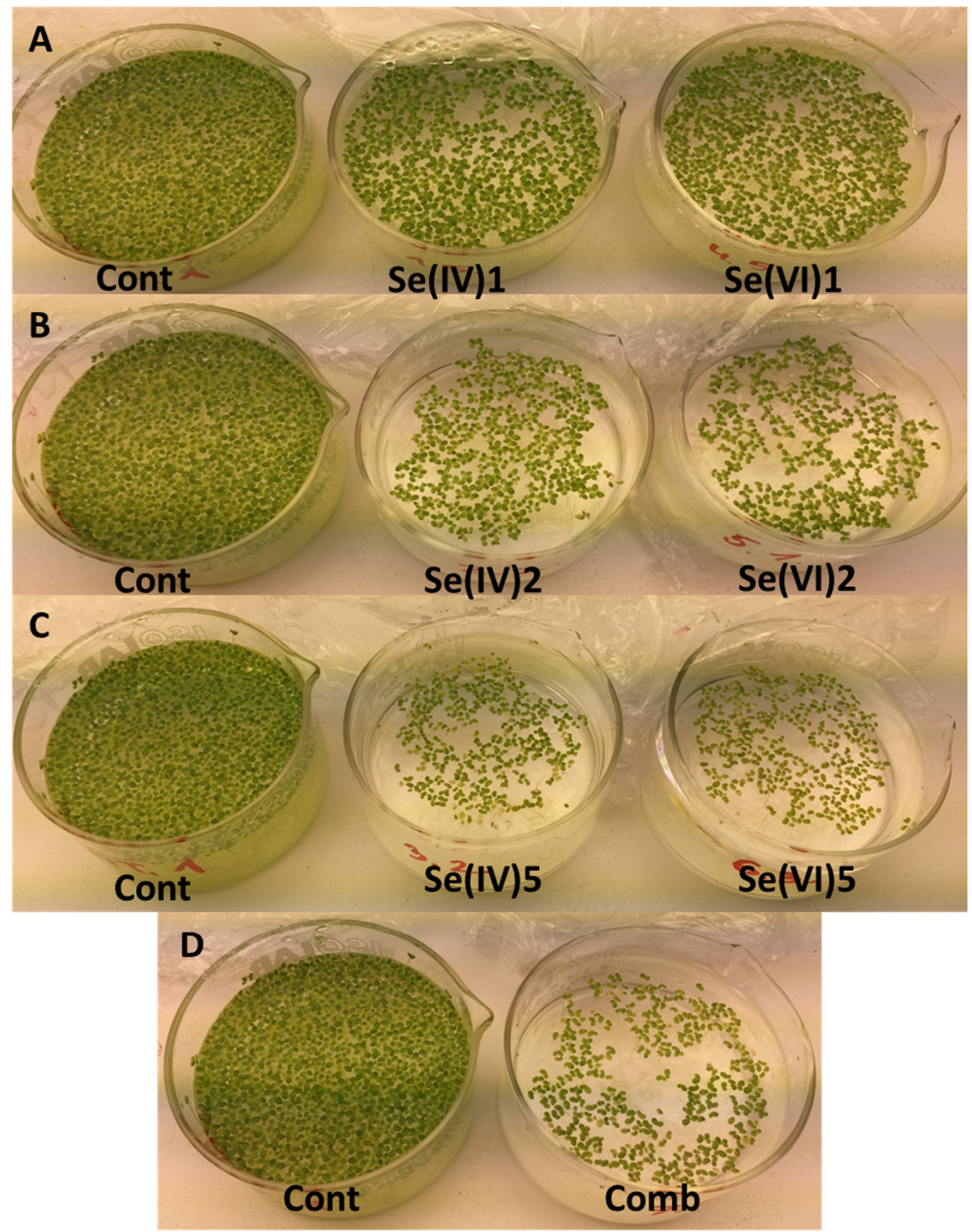

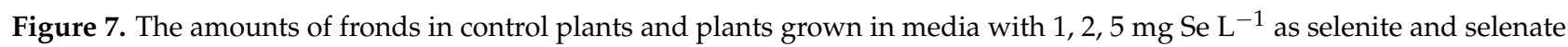
and as a combination of selenite and selenate, after 1 week of growth. Legend: Cont, control; Se(IV)1, 2, 5, selenite at 1, 2, $5 \mathrm{mg} \mathrm{Se} \mathrm{L}{ }^{-1}$; Se(VI)1, 2, 5, selenate at 1, 2, $5 \mathrm{mg} \mathrm{Se} \mathrm{L}^{-1}$; Comb, selenite and selenate at $4 \mathrm{mg} \mathrm{Se} \mathrm{L}^{-1}$ (i.e., $2+2$ ).

For $\mathrm{BCF}$, the highest was observed for plants grown in growth media with selenate. At 1 and $2 \mathrm{mg} \mathrm{Se} \mathrm{L}^{-1}$ in the form of selenate, BCF reached its peak (153, 166, respectively) and then decreased at $5 \mathrm{mg}$ Se $\mathrm{L}^{-1}$. BCF for duckweed treated with selenite was lower compared to that of selenate, and also decreased with higher concentrations of Se in growth media (Table 2). 


\subsection{Concentrations of Elements}

The uptake of selenite in the duckweed increased almost linearly with increasing concentrations of selenite (from 0 to $5 \mathrm{mg} \mathrm{Se} \mathrm{L}^{-1}$ ) in the media (Table 3). For selenate, the uptake of Se from growth medium initially increased linearly, up to $2 \mathrm{mg} \mathrm{Se}^{-1}$. Here, at $5 \mathrm{mg}$ Se $\mathrm{L}^{-1}$, however, the uptake decreased. Duckweed accumulated more Se in their tissue when Se was added in the form of selenate, compared to selenite. The highest contents of Se contained in the duckweed grown in growth medium with the addition of selenate was at $2 \mathrm{mg} \mathrm{Se} \mathrm{L}^{-1}$ (Table 3).

Table 3. Concentrations of selenium, calcium and potassium in the duckweed after 1 week of treatments.

\begin{tabular}{|c|c|c|c|}
\hline \multirow[b]{2}{*}{ Treatment } & \multicolumn{3}{|c|}{ Content of Elements } \\
\hline & $\begin{array}{c}\text { Selenium } \\
\left(\mu \mathrm{g} \mathrm{g}^{-1} \mathrm{DW}\right)\end{array}$ & $\begin{array}{c}\text { Calcium } \\
\left(\mathrm{mg} \mathrm{g}^{-1} \mathrm{DW}\right)\end{array}$ & $\begin{array}{c}\text { Potassium } \\
\left(\mathrm{mg} \mathrm{g}^{-1} \mathrm{DW}\right)\end{array}$ \\
\hline Cont & $1.2 \pm 0.1^{f}$ & $8.3 \pm 0.7^{a}$ & $22 \pm 0.9^{a}$ \\
\hline Se(VI)1 & $153 \pm 6.0^{d}$ & $5.5 \pm 0.3^{c}$ & $22 \pm 0.9^{a}$ \\
\hline $\mathrm{Se}(\mathrm{VI}) 2$ & $332 \pm 7.8^{a}$ & $5.3 \pm 0.2^{\mathrm{cd}}$ & $21 \pm 0.3^{\mathrm{a}}$ \\
\hline Se(VI)5 & $277 \pm 13.9^{b}$ & $5.4 \pm 0.4^{\mathrm{cd}}$ & $14 \pm 0.5^{\mathrm{cb}}$ \\
\hline Se(IV)1 & $99 \pm 4.0^{\mathrm{e}}$ & $7.2 \pm 0.4^{b}$ & $23 \pm 1.4^{\mathrm{a}}$ \\
\hline $\mathrm{Se}(\mathrm{IV}) 2$ & $159 \pm 4.4^{\mathrm{d}}$ & $4.8 \pm 0.4^{\mathrm{cd}}$ & $23 \pm 1.4^{\mathrm{a}}$ \\
\hline Se(IV)5 & $227 \pm 7.4^{\mathrm{c}}$ & $4.3 \pm 0.2^{\mathrm{d}}$ & $12 \pm 0.4^{\mathrm{c}}$ \\
\hline Comb & $263 \pm 2.8^{b}$ & $4.4 \pm 0.2^{\mathrm{cd}}$ & $15 \pm 1.0^{b}$ \\
\hline
\end{tabular}

Legend: Data are means $\pm \mathrm{SE}(\mathrm{N}=5)$. Data indicated with different letters were significantly different $(p<0.05)$ DW, dry weight; Cont, control; Se(IV)1, 2, 5, selenite at 1, 2, $5 \mathrm{mg} \mathrm{Se} \mathrm{L}^{-1}$; Se(VI)1, 2, 5, selenate at 1, 2, $5 \mathrm{mg} \mathrm{Se} \mathrm{L}^{-1}$; $\mathrm{Comb}$, selenite and selenate at $4 \mathrm{mg} \mathrm{Se}^{-1}$ (i.e., $2+2$ ).

Regardless of its concentration and form, the presence of Se in the growth media significantly reduced the amounts of $\mathrm{Ca}$ in the duckweed tissue. The Ca concentration in the control group was $8.3 \pm 0.7 \mathrm{mg} \mathrm{g}^{-1} \mathrm{DW}$, and this decreased in all of the groups treated with Se (Table 3). The presence of Se in the growth media also reduced the amounts of $\mathrm{K}$ in the duckweed tissue, but only at $5 \mathrm{mg} \mathrm{Se} \mathrm{L}^{-1}$ for both selenite and selenate, and for their combination at $2 \mathrm{mg} \mathrm{Se} \mathrm{L}^{-1}$ each(Table 3). The Se contents in the duckweed tissue were negatively correlated with the $\mathrm{Ca}$ and $\mathrm{K}$ concentrations.

Redundancy analysis revealed that leaf Se, Ca and K contents significantly affected the biochemical, physiological and growth parameters of duckweed (Figure 8). The content of $\mathrm{K}$ in duckweed tissue explained $39 \%$ of the variability $(p=0.003)$, with Se content explaining an additional 14\% ( $p=0.003)$, and Ca content an additional $4 \%(p=0.024)$ of the variability of the biochemical, physiological and growth parameters of duckweed. The biochemical, physiological and growth parameters of duckweed were negatively related to the duckweed Se concentration, and positively affected by the Ca and K concentrations (Figure 8). 


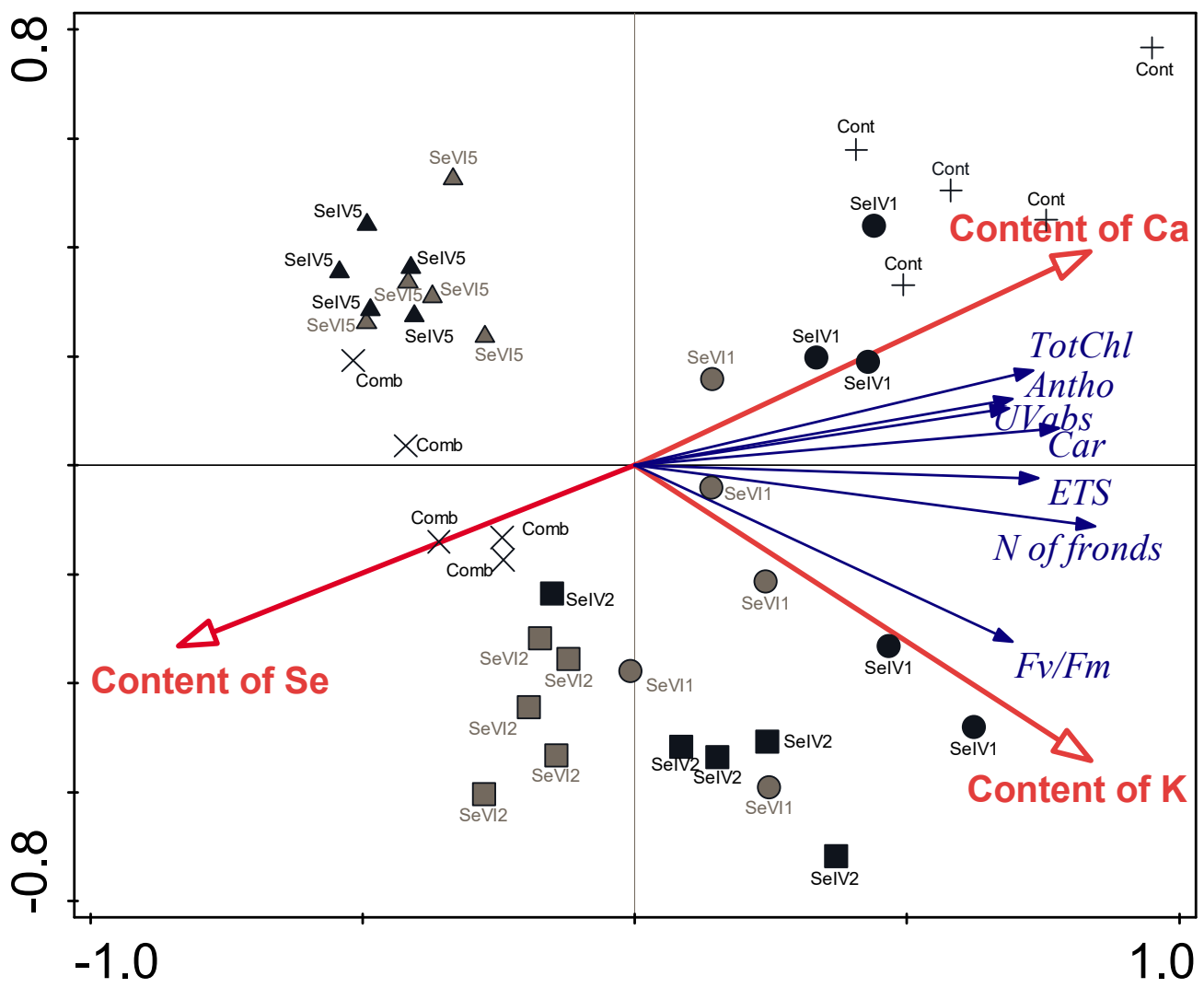

Figure 8. Redundancy analysis plot showing the strengths of the associations between some of the element contents (Se, Ca, K) in duckweed and the plant biochemical, physiological and growth parameters. Legend: Cont, control; Se(IV)1, 2, 5, selenite at 1, 2, $5 \mathrm{mg} \mathrm{Se} \mathrm{L}^{-1}$; $\mathrm{Se}(\mathrm{VI}) 1,2$, 5, selenate at

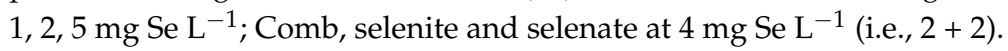

\section{Discussion}

\subsection{Physiological Characteristics}

Data on terminal ETS activity in mitochondria provide an assessment of the general metabolic activity of organisms. When organisms are exposed to stress conditions, they demand more energy [32,43]. ETS activity was lower in the Se-treated plants compared to the controls. Treatments of the plants with sodium selenite, sodium selenate, and the combination of sodium selenite and sodium selenate was stressful or unfavourable, which is reflected in a decrease in ETS activity. Lower respiratory potential can be a result of disturbances in the electron-transfer process in the respiratory chain [29,44], and reduced respiratory enzyme capacity [45]. Our results also indicate that $L$. minor was the most sensitive to the high Se concentration $\left(5 \mathrm{mg} \mathrm{Se} \mathrm{L}^{-1}\right)$, regardless of the Se chemical form. Additionally, Mechora et al. [29] reported that higher concentrations of selenite (2, 5, $10 \mathrm{mg} \mathrm{Se} \mathrm{L}^{-1}$ ) negatively affected ETS and potential photochemical efficiency of PS II in L. minor. While they also reported that treatment of plants with selenite at $1 \mathrm{mg} \mathrm{Se} \mathrm{L}^{-1}$ increased the respiratory potential, compared to control plants, we cannot claim this based on our results.

From our analysis of ETS activity, it is not possible to determine whether selenite is more toxic than selenate, and vice versa. Therefore, we cannot confirm the findings of Terry et al. [46], that selenite was more toxic than selenate for macrophytes, here. In addition, some other aquatic plants, such as Myriophyllum spicatum, Potamogeton perfoliatus and Ceratophyllum demersum, have been exposed to $10 \mathrm{mg} \mathrm{Se} \mathrm{L}^{-1}$ in the form of selenite, and these expressed lower ETS activity compared to the control [30]. Mechora et al. [29] also reported that $10 \mathrm{mg} \mathrm{Se} \mathrm{L}^{-1}$ in the form of selenite was toxic for L. minor. This applies not only to aquatic plants, but also to terrestrial plants, such as Cucurbita pepo and Glycine 
max cv. Olna, where ETS activities were shown to be lower in plants foliarly treated with Se compared to the control [44,47].

In addition to the respiratory potential, the photochemical efficiency of PS II is one of the reliable indicators of the presence of stress in plants. The potential photochemical efficiency of PS II expressed as the Fv / Fm ratio in vital plants growing under favourable conditions can reach 0.83 , which is the theoretical maximum [34]. Treatment of L. minor with $5 \mathrm{mg} \mathrm{Se} \mathrm{\textrm {L } ^ { - 1 }}$ in any form and combination lowered the potential photochemical efficiency of PS II in the present study. This indicates that the addition of Se at this concentration caused irreversible damage to the electron chain in PS II.

Treatment of the aquatic plants M. spicatum and C. demersum with $10 \mathrm{mg} \mathrm{Se} \mathrm{L}^{-1}$ in the form of selenite or selenate has also shown negative effects on the potential photochemical efficiency of PS II, compared to control plants [30,31]. Selenite and selenate at the highest concentration we used here $\left(5 \mathrm{mg} \mathrm{Se} \mathrm{L}^{-1}\right)$ have the most adverse effects on plants, with the greatest damage seen to the photosynthesis apparatus. This was also noted by Severi [10]. However, in this study, a low Se concentration $\left(1 \mathrm{mg} \mathrm{Se} \mathrm{L}^{-1}\right)$ in the form of selenite and selenate increased the multiplication ratio, which is in contrast to our findings, where $1 \mathrm{mg} \mathrm{Se} \mathrm{\textrm {L } ^ { - 1 }}$ in the form of selenite and selenate adversely affected the plant characteristics. In the fourth trial here, L. minor treated with $5 \mathrm{mg} \mathrm{Se}^{-1}$ in the form of selenite had lower photochemical potency of PS II compared to the plants treated with $5 \mathrm{mg} \mathrm{Se} \mathrm{L}^{-1}$ in the form of selenate. Thus, here we can conclude that for L. minor, selenite is more toxic than selenate, confirming the studies of Terry et al. [46] and Mechora et al. [29,30], who observed that for macrophytes, selenite was more toxic than selenate.

It is believed that selenite is more harmful for plants because it is more easily converted to Se amino acids, like SeCys and SeMet, which interfere with normal protein production [48]. To protect against its toxicity, in terrestrial plants, selenite is less mobile and is retained in the roots. In L. minor, the roots are reduced to a high degree, as the plants absorb nutrients from the water through all of their surface. It is possible that $S e$ in the form of selenite in L. minor (which has a thin epidermis) reached the inner part of the plants and chloroplasts, where it can interfere with amino acids and disrupt the function of proteins. Severi [10] stated that at high sulphur concentrations, sodium selenite appears more toxic than sodium selenate, whereas at low sulphur concentrations, sodium selenate was the most toxic to L. minor. In addition, Tarrahi et al. [49] reported that Se nanoparticles inhibited growth and photosynthetic activities of L. minor, which resulted in anti-oxidative responses as a defence mechanism for survival in the presence of this toxicant.

\subsection{Biochemical Characteristics}

Lemna minor grown in media with added selenite or selenate at $5 \mathrm{mg} \mathrm{Se} \mathrm{L}^{-1}$ and as a combination had significantly lower chlorophylls content than control plants in most of the trials. Se might inhibit the synthesis of chlorophylls or cause their destruction. A decrease in chlorophyll content in P. perfoliatus treated with $10 \mathrm{mg} \mathrm{Se} \mathrm{L}^{-1}$ in the form of selenite was also observed by Mechora et al. [30]. Likewise, Mechora et al. [31] reported that M. spicatum and $C$. demersum treated with $10 \mathrm{mg} \mathrm{Se} \mathrm{L}^{-1}$ in the form of selenate had negative effects on chlorophyll content, compared to control plants. Akbulut and Çakır [50] attributed lower chlorophyll contents in Se-treated barley plants to limited chlorophyll synthesis. In their study with the alga Scenedesmus quadricauda, Se was added to the nutrient medium as either sodium selenite or sodium selenate at 50 and $100 \mathrm{mg} \mathrm{Se} \mathrm{L}^{-1}$. They observed ultrastructural damage to the chloroplasts, which indicated that these are important targets in the mechanism of Se toxicity. Results have shown that the chloroplasts were not so heavily affected by selenite exposure [51]. It was seen again that selenite was more toxic for aquatic plants compared to selenate.

The carotenoids contents were generally the lowest in plants grown in media with the addition of selenite, selenate and their combination. Often, an increase in carotenoid content is part of the plant adaptive strategies at times of exposure to stressors. For severe stress, the protective system can be overloaded, which leads to oxidative damage to the 
carotenoids and to decreased contents of these protective molecules [52]. In line with our results, Severi [10] showed that Se lowered the carotenoids contents in L. minor exposed to 10 and $20 \mathrm{mg} \mathrm{Se} \mathrm{L}^{-1}$ in the form of selenite. Contrary to our results, Mechora et al. [29] reported that the carotenoid contents decreased in the treated plants of L. minor with $0.5 \mathrm{mg}$ Se $\mathrm{L}^{-1}$ selenite, while the carotenoid contents increased in the plants with added 1 , $2,5 \mathrm{mg} \mathrm{Se} \mathrm{L}^{-1}$ in the form of selenite.

The anthocyanin content in control plants was never lower than the anthocyanin contents of plants treated with selenite, selenate and their combination. Synthesis of anthocyanins is stimulated under stress conditions [53]. However, if the stress is too severe, their accumulation decreases, as evident in the present study. Mechora et al. [30], however, reported that the amounts of anthocyanins were not affected by treatments with Se in $M$. spicatum, C. demersum and P. perfoliatus plants as low $\left(20 \mu \mathrm{g} \mathrm{Se} \mathrm{L}{ }^{-1}\right)$ and high $\left(10 \mathrm{mg} \mathrm{Se} \mathrm{L}^{-1}\right)$ concentrations in the form of selenite. The UV-B and UV-A contents decreased in treated plants. Charron et al. [54] observed that fertilisation of Brassica oleracea with Se generally decreased the levels of glucosinolates to a certain extent, which indicated that the selection of one biologically active component (Se) might also reduce the contents of other bioactive components, such as phenols and glucosinolates.

\subsection{Growth Characteristics}

Inhibited growth can be one of the most common responses of plants to stress conditions [55]. In addition to visible growth, the colour of the fronds is a good indicator of stress in plants [29]. The number of fronds generally decreased with increasing concentrations of Se in any form and combination. These results indicate that impaired photosynthetic activity inhibited the growth of L. minor. In addition to limiting growth, we also noted

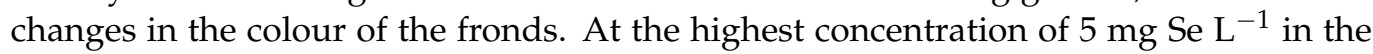
form of selenite and selenate and for the combination of selenite and selenate, the decay of plants was most noticeable. This can be seen from the lower numbers and smaller sizes of the fronds. The roots also began to fall off and sink to the bottom of the crystallising dishes, with the appearance also of brown dots, greater chlorosis and necrosis of the fronds, and yellow fronds. The fronds in the treated plants were no longer associated in the colonies. The fronds of the control plants were more prominent and greener in colour, which indicated good plant vitality. Se probably interrupted the function of enzymes by incorporate on at the location of sulphur. In addition, selenite and selenate might act as prooxidants in cells of L. minor, which all cause lower growth and damage to plant tissue. Pistone et al. [18] reported that fronds were separated from each other and were smaller

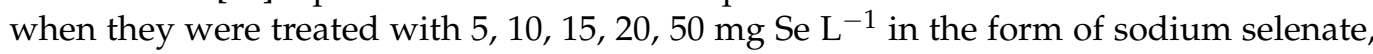
compared to control plants. Mechora et al. [29] reported that higher concentrations of Se

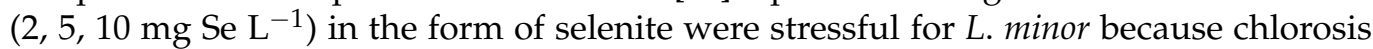
occurred, and plant growth decreased. Severi [10] showed, however, that selenite and selenate generally reduced the growth and multiplication rate of L. minor, although at some low concentrations $\left(1 \mathrm{mg} \mathrm{Se} \mathrm{L}^{-1}\right)$, this increased the multiplication rate, which is in turn contrary to our findings.

\subsection{Elemental Composition of L. Minor}

The amount of Se in the tissue in the present study increased with increase of Se in the growth medium, regardless of the form of Se. The amount of Se in the fronds was higher when Se was added in the form of selenate than in the form of selenite. There are not a lot of studies regarding the absorption of Se by macrophytes from the water and sediment. Mechora et al. [30] exposed three macrophytes to different concentrations of selenite. They showed that the concentration of Se in plants cultured in $10 \mathrm{mg} \mathrm{Se} \mathrm{L}^{-1}$ ranged from 436 to $839 \mu \mathrm{g}$ Se $\mathrm{g}^{-1} \mathrm{DW}$ in M. spicatum, 319 to $988 \mu \mathrm{g}$ Se $\mathrm{g}^{-1} \mathrm{DW}$ in C. demersum and 310 to $661 \mu \mathrm{g} \mathrm{Se}{ }^{-1} \mathrm{DW}$ in $P$. perfoliatus. The concentration of Se added to the growth media in our study was at least lower. However, we can conclude that L. minor absorbs higher concentrations of Se from the water compared to M. spicatum, C. demersum and P. perfoliatus. 
L. minor has very thin fronds and this is probably the reason for its efficient absorption of Se from the water. That was also indicated by the estimation of $\mathrm{BCF}$, which is an assessment of plant accumulation of elements with respect to the element concentration in the growth medium [41]. In the present study, the highest BCFs were for duckweed grown in media with selenite, compared to selenate. Furthermore, BCFs for duckweed decreased for the higher concentrations of Se. In one of the early studies, Besser et al. [56] reported that macrophytes had much lower BCFs for selenate comparing to selenite. The lower $\mathrm{BCF}$ for Se added as selenate suggested that bioaccumulation and biotransformation of selenate was slower than that of selenite. Zayed et al. [41] investigated the potential of duckweed (L. minor L.) to accumulate Se when supplied in a nutrient solution at a series of concentrations that ranged from 0.1 to $10 \mathrm{mg} \mathrm{Se} \mathrm{L}^{-1}$. Their results showed that under their experimental conditions, duckweed was a good accumulator of Se. The highest concentrations accumulated in duckweed tissues was $4.27 \mathrm{~g} \mathrm{Se} \mathrm{kg}^{-1}$. The BCF of 427 was higher at $10 \mathrm{mg} \mathrm{Se} \mathrm{L}^{-1}$ than that at $0.1 \mathrm{mg} \mathrm{Se} \mathrm{L}^{-1}$ (273). In addition, in a recent phytoremediation study, Nattrass et al. [23] showed that Se removal was significantly less effective in microcosms supplied with selenate compared to selenite. After 6 days at $500 \mathrm{ppb}$ Se in the form of selenate, duckweed removal efficiencies were greater than $50 \%$ of the applied aqueous Se. The results indicated that duckweed is a promising species for phytoremediation of water polluted with Se. Plants of L. minor containing high amounts of Se can be safely removed from polluted ecosystems and be used in animal consumption, unless they contain too high amounts of Se or other potentially toxic elements.

In most of the studies, selenite and selenate are used as separate Se treatments. Thus, in the present study, we also investigated simultaneous intake of both Se species. We compared Se content in the fronds of $L$. minor exposed to 2 and $5 \mathrm{mg} \mathrm{Se} \mathrm{L}^{-1}$ in the form of selenite, with Se content in those exposed to $2 \mathrm{mg} \mathrm{Se} \mathrm{L}^{-1}$ in the form of selenite and $2 \mathrm{mg} \mathrm{Se} \mathrm{L^{-1 }}$ in the form of selenate (total Se concentration, $4 \mathrm{mg} \mathrm{L}^{-1}$ ), with higher Se concentrations seen for the combination. As far as we know, there are no such studies regarding aquatic plants. The present data are also in agreement with the results of Kacjan Maršić et al. [57], where for foliar addition of Se to Spinaciea oleracea L., the Se contents in the spinach plants exposed to mixtures of both of these forms of Se were higher than those of the plants treated with Se in the form of selenite at the same concentration of Se.

The contents of Se in L. minor tissue were negatively related to their physiological, biochemical and morphological characteristics, as well as to their contents of $\mathrm{Ca}$ and $\mathrm{K}$. On the other hand, there was a significant positive correlation between the concentrations of $\mathrm{Ca}$ and $\mathrm{K}$ in duckweed tissue and their physiology and growth. Such results were expected, as it is known that Ca has a dual function, both as a structural component of cell walls and membranes, and as an intracellular second messenger [58]. On the other hand, $\mathrm{K}$ is the most abundant inorganic cation, and it is important to ensure optimal plant growth. $\mathrm{K}$ is an activator of many important enzymes, such as those for protein synthesis, sugar transport, nitrogen and carbon metabolism, and photosynthesis [59]. The results of the present study suggest that Se affects L. minor metabolism also indirectly, through effects on the uptake of other nutrients from the growth medium, such as Ca and K.

The number of fronds was the lowest at high added Se. At that concentration, there was also the most prominent occurrence of fronds with chlorosis, which indicated a high level of toxicity, as reported by Mechora et al. [30]. In a study by Zayed et al. [41], duckweed showed $26 \%$ growth reduction and visual symptoms of toxicity (e.g., chlorosis)

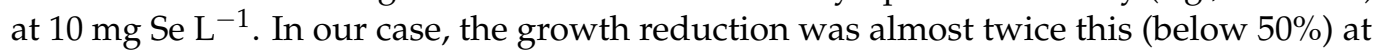
half the concentration of Se in the growth medium. This might also be a consequence of the effect of Se on Ca uptake, and at higher concentrations, on K uptake. Th amounts of $\mathrm{K}$ were similar in fronds exposed to 1 and $2 \mathrm{mg} \mathrm{Se} \mathrm{L}^{-1}$ regardless of the Se form, and then this gradually decreased for the exposure to the highest Se $\left(5 \mathrm{mg} \mathrm{Se} \mathrm{L}^{-1}\right)$ and to the combination of both forms of Se. It can be concluded that Se in any form down-regulates accumulation of $\mathrm{Ca}$ and $\mathrm{K}$ in the plant fronds. 
On the other hand, it is also possible that toxicity is caused by $\mathrm{Na}$, as Se was added in the form of sodium selenate and sodium selenite. The mechanism remains unclear. It is possible that Se, and probably even more likely the Na that is present at high amounts, compete with the $\mathrm{K}$ transporters for entering the plants in the case of L. minor. The physiological consequences of such antagonism are, however, still unclear. We believe that sodium might also have negative effects on the biochemical and physiological characteristics of L. minor. Keppeler et al. [60] showed that even with $6.00 \mathrm{~g} \mathrm{~L}^{-1} \mathrm{NaCl}$, there was substantial inhibition of growth of L. minor, especially with exposure times of $72 \mathrm{~h}$ and $96 \mathrm{~h}$, with greater effects at the longer time. Similarly, Forni et al. [61] reported that sodium dodecyl sulphate affected duckweed enzymatic activities and phenol contents involved in the detoxification system of L. minor, thus improving their tolerance. However, Na-Se salts were added in trace amounts of 1,2 and 5 ppm, so consequentially also Na was added in trace amounts. According to the literature, these Na concentrations are non-toxic for Lemna, since it can tolerate up to $100 \mathrm{mM}$ of $\mathrm{NaCl}$ [62]. Higher toxicity to $\mathrm{Na}$ compared to Se for duckweed could be confirmed with similar experiments using potassium selenite and potassium selenate for the addition to the growth medium.

Treatment of L. minor plants at any concentrations of sodium selenite or sodium selenate and the combination of selenite and selenate induced a worse physiological state and lower concentrations of photosynthetic pigments compared to the control, which indicated that the plants were exposed to stress conditions even at the lowest concentrations of selenite and selenate in the growth media. The concentrations of Se used in the present study were comparable or even higher than the concentrations of Se in Se-polluted waters from seleniferous areas [63]. Our findings suggest that L. minor is a species that can accumulation high amounts Se; however, concentrations of Se in the medium $>1 \mathrm{mg} \mathrm{L}^{-1}$ resulted in negative effects on growth. The responses for the physiological and growth parameters were in proportion to the degree of Se contamination in the media, which is one of the most important characteristics of a good indicator organism. Sensitivity of $L$. minor to Se contamination indicated that it can be used as a bioindicator of water polluted with Se. However, additional research is needed to exclude the possible negative effects of $\mathrm{Na}$ in the treatment medium.

\section{Conclusions}

Treatment of L. minor plants with $1,2,5 \mathrm{mg} \mathrm{Se}^{-1}$ in the form of sodium selenite or

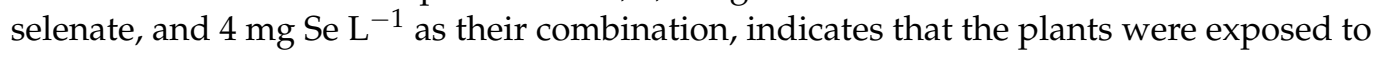
stress conditions even at the lowest concentrations in the growth media. It can be assumed that due to severe stress, damage to the metabolism of L. minor plants resulted in decreased tissue vitality, reduced photosynthetic activity, and degradation. This is reflected in the plants treated with selenite, selenate and their combination by the lower ETS activities, and the reduced potential photochemical efficiency of PS II, content of photosynthetic pigments, anthocyanin content, UV-A and UV-B absorbing compounds content and the number fronds, and the increased chlorosis and necrosis. These responses were the strongest in the plants treated with the highest Se concentrations.

It is shown here that a large amount of Se was concentrated in the tissue of the duckweed plants, which indicated the good phytoremediation potential of these plants. Thus, using common duckweed in phytoremediation processes is promising. However, Se at $5 \mathrm{mg} \mathrm{L}^{-1}$ also severely impaired the physiological, biochemical and growth characteristics of the plants. Both of these results indicate that L. minor can also be used as a bioindicator for water pollution. Thus, the concentration of Se in polluted water will be an important factor in the phytoremediation potential of duckweed. Additional studies are also needed to evaluate the effects on L. minor of $\mathrm{Na}$ in the treatment medium. 
Author Contributions: Conceptualisation, K.V.-M. and A.G.; methodology, A.G.; software, A.G.; validation, A.G., K.V.-M. and M.G.; formal analysis, A.G., N.B. and K.V.-M.; investigation, N.B.; resources, M.G.; data curation, M.G.; writing-original draft preparation, M.G.; writing-review and editing, A.G. and K.V.-M.; visualisation, M.G.; supervision, K.V.-M.; funding acquisition, K.V.-M. All authors have read and agreed to the published version of the manuscript.

Funding: This research was funded by the SLOVENIAN RESEARCH AGENCY, grant number "P1-0212", "J7-9418" and "N1-0105".

Institutional Review Board Statement: Not applicable.

Informed Consent Statement: Not applicable.

Data Availability Statement: Not applicable.

Acknowledgments: The authors are grateful to Dragan Abram, for his help with some of the experimental measurements and technical support and Christopher Berrie for revising the English text.

Conflicts of Interest: The authors declare no conflict of interest.

\section{References}

1. Ellis, D.R.; Salt, D.E. Plants, selenium and human health. Curr. Opin. Plant Biol. 2003, 6, 273-279. [CrossRef]

2. Hasanuzzaman, M.; Bhuyan, M.B.; Raza, A.; Hawrylak-Nowak, B.; Matraszek-Gawron, R.; Al Mahmud, J.; Nahar, K.; Fujita, M. Selenium in plants: Boon or bane? Environ. Exp. Bot. 2020, 178, 104170. [CrossRef]

3. Naseem, M.; Anwar-Ul-Haq, M.; Wang, X.; Farooq, N.; Awais, M.; Sattar, H.; Malik, H.A.; Mustafa, A.; Ahmad, J.; El-Esawi, M.A. Influence of Selenium on Growth, Physiology, and Antioxidant Responses in Maize Varies in a Dose-Dependent Manner. J. Food Qual. 2021, 2021, 1-9. [CrossRef]

4. Seppänen, M.; Turakainen, M.; Hartikainen, H. Selenium effects on oxidative stress in potato. Plant Sci. 2003, 165, 311-319. [CrossRef]

5. Abbas, S.M. Effects of low temperature and selenium application on growth and the physiological changes in sorghum seedlings. J. Stress Physiol. Biochem. 2012, 8, 268-286.

6. Hasanuzzaman, M.; Hossain, M.A.; Fujita, M. Selenium-Induced Up-Regulation of the Antioxidant Defense and Methylglyoxal Detoxification System Reduces Salinity-Induced Damage in Rapeseed Seedlings. Biol. Trace Element Res. 2011, 143, $1704-1721$. [CrossRef] [PubMed]

7. Hawrylak-Nowak, B.; Dresler, S.; Wójcik, M. Selenium affects physiological parameters and phytochelatins accumulation in cucumber (Cucumis sativus L.) plants grown under cadmium exposure. Sci. Hortic. 2014, 172, 10-18. [CrossRef]

8. Nawaz, F.; Ashraf, M.; Ahmad, R.; Waraich, E.; Shabbir, R.; Bukhari, M. Supplemental selenium improves wheat grain yield and quality through alterations in biochemical processes under normal and water deficit conditions. Food Chem. 2015, 175, 350-357. [CrossRef] [PubMed]

9. Kabata-Pendias, A. Trace Elements in Soils and Plants, 4th ed.; Taylor \& Francis Group: London, UK, 2010; p. 548. Available online: https:/ / doi.org/10.1201/b10158 (accessed on 18 October 2010).

10. Severi, A. Toxicity of selenium to Lemna minor in relation to sulfate concentration. Physiol. Plant. 2001, 113, 523-532. [CrossRef]

11. Landrigan, P.J.; Fuller, R.; Acosta, N.J.R.; Adeyi, O.; Arnold, R.; Basu, N.N.; Baldé, A.B.; Bertollini, R.; Bose-O'Reilly, S.; Boufford, J.I.; et al. The Lancet Commission on pollution and health. Lancet 2018, 391, 462-512. [CrossRef]

12. Haug, A.; Graham, R.D.; Christophersen, O.A.; Lyons, G.H. How to use the world's scarce selenium resources efficiently to increase the selenium concentration in food. Microb. Ecol. Health Dis. 2007, 19, 209-228. [CrossRef]

13. Winkel, L.H.E.; Johnson, C.A.; Lenz, M.; Grundl, T.; Leupin, O.X.; Amini, M.; Charlet, L. Environmental Selenium Research: From Microscopic Processes to Global Understanding. Environ. Sci. Technol. 2011, 46, 571-579. [CrossRef] [PubMed]

14. Navarro-Alarcon, M.; Cabrera-Vique, C. Selenium in food and the human body: A review. Sci. Total. Environ. 2008, 400, 115-141. [CrossRef] [PubMed]

15. Santos, S.; Ungureanu, G.; Boaventura, R.; Botelho, C. Selenium contaminated waters: An overview of analytical methods, treatment options and recent advances in sorption methods. Sci. Total. Environ. 2015, 521-522, 246-260. [CrossRef]

16. Zhou, C.; Huang, J.-C.; Liu, F.; He, S.; Zhou, W. Selenium removal and biotransformation in a floating-leaved macrophyte system. Environ. Pollut. 2019, 245, 941-949. [CrossRef]

17. Dhote, S.; Dixit, S. Water quality improvement through macrophytes-a review. Environ. Monit. Assess. 2009, 152, 149-153. [CrossRef]

18. Pistone, G.; Allinson, G.; Stagnitti, F.; Colville, S. Effect of selenium on the growth ofLemna minor. Toxicol. Environ. Chem. 1999, 71, 271-277. [CrossRef]

19. Ziegler, P.; Sree, K.; Appenroth, K.-J. Duckweeds for water remediation and toxicity testing. Toxicol. Environ. Chem. 2016, 98, 1127-1154. [CrossRef]

20. Ghanem, H.; Haddad, A.; Baydoun, S.; Hamdan, H.A.; Korfali, S.; Chalak, L. In vitro proliferation of Lebanese Lemna minor and Lemna gibba on different nutrient media. J. Taibah Univ. Sci. 2019, 13, 497-503. [CrossRef] 
21. Forni, C.; Tommasi, F. Duckweed: A Tool for Ecotoxicology and a Candidate for Phytoremediation. Curr. Biotechnol. 2016, 5, 2-10. [CrossRef]

22. Carvalho, K.; Martin, D. Removal of Aqueous Selenium by Four Aquatic Plants. J. Aquat. Plant Manag. 2001, 39, $33-36$.

23. Nattrass, M.; McGrew, N.R.; Morrison, J.I.; Baldwin, B.S. Phytoremediation of selenium-impacted water by aquatic macrophytes. J. Am. Soc. Min. Reclam. 2019, 8, 69-79. [CrossRef]

24. Vladimirova, I.N.; Georgiyants, V.A. Biologically Active Compounds from Lemna Minor S.F. Gray. Pharm. Chem. J. 2014, 47, 599-601. [CrossRef]

25. Kastratović, V.; Jaćimović, Ž.; Đurović, D.; Bigović, M.; Krivokapić, S. Lemna minor L. As Bioindicator Of Heavy Metal Pollution In Skadar Lake: Montenegro. Kragujev. J. Sci. 2015, 37, 123-134. [CrossRef]

26. Li, H.; Mo, F.; Li, Y.; Wang, M.; Li, Z.; Hu, H.; Deng, W.; Zhang, R. Effects of silver(I) toxicity on microstructure, biochemical activities, and genic material of Lemna minor L. with special reference to application of bioindicator. Environ. Sci. Pollut. Res. 2020, 27, 22735-22748. [CrossRef]

27. Pollard, J.; Cizdziel, J.; Stave, K.; Reid, M. Selenium concentrations in water and plant tissues of a newly formed arid wetland in Las Vegas, Nevada. Environ. Monit. Assess. 2007, 135, 447-457. [CrossRef]

28. Delmail, D.; Labrousse, P.; Hourdin, P.; Larcher, L.; Moesch, C.; Botineau, M. Physiological, anatomical and phenotypical effects of a cadmium stress in different-aged chlorophyllian organs of Myriophyllum alterniflorum DC (Haloragaceae). Environ. Exp. Bot. 2011, 72, 174-181. [CrossRef]

29. Mechora, Š; Stibilj, V.; Germ, M. Response of duckweed to various concentrations of selenite. Environ. Sci. Pollut. Res. 2014, 22, 2416-2422. [CrossRef]

30. Mechora, S.; Stibilj, V.; Germ, M. The uptake and distribution of selenium in three aquatic plants grown in Se(IV) solution. Aquat. Toxicol. 2013, 128-129, 53-59. [CrossRef]

31. Mechora, Š; Cuderman, P.; Stibilj, V.; Germ, M. Distribution of Se and its species in Myriophyllum spicatum and Ceratophyllum demersum growing in water containing se (VI). Chemosphere 2011, 84, 1636-1641. [CrossRef] [PubMed]

32. Packard, T.T. The Measurement of Respiratory Electron-transport Activity tn Marine Phytoplankton. J. Mar. Res. 1971, 29, 235-243.

33. Kenner, R.A.; Ahmed, S.I. Measurements of electron transport activities in marine phytoplankton. Mar. Biol. 1975, 33, 119-127. [CrossRef]

34. Schreiber, U.; Bilger, W.; Neubauer, C. Chlorophyll fluorescence as a nonintrusive indicator for rapid assessment of in vivo photosynthesis. In Ecophysiology of Photosynthesis; Springer: Berlin/Heidelberg, Germany, 1995; pp. 49-70. [CrossRef]

35. Lichtenthaler, H.K. Chlorophylls and carotenoids: Pigments of photosynthetic biomembranes. Methods Enzymol. 1987, 148, 350-382.

36. Lichtenthaler, H.K.; Buschmann, C. Chlorophylls and Carotenoids: Measurement and Characterization by UV-VIS Spectroscopy. Curr. Protoc. Food Anal. Chem. 2001, 1, F4.3.1-F4.3.8. [CrossRef]

37. Drumm, H.; Mohr, H. The mode of interaction between blue (uv) light photoreceptor and phytochrome in anthocyanin formation of the sorghum seedling. Photochem. Photobiol. 1978, 27, 241-248. [CrossRef]

38. Caldwell, M.M. Solar Ultraviolet Radiation as an Ecological Factor for Alpine Plants. Ecol. Monogr. 1968, 38, 243-268. [CrossRef]

39. Kump, P.; Nečemer, M.; Rupnik, Z.; Pelicon, P.; Ponikvar, D.; Vogel-Mikuš, K.; Regvar, M.; Pongrac, P. Improvement of the XRF Quantification and Enhancement of the Combined Applications by EDXRF and Micro PIXE. 2011. Available online: https://inis.iaea.org/search/search.aspx?orig_q=RN:43021135 (accessed on 15 October 2021).

40. Nečemer, M.; Kump, P.; Ščančar, J.; Jaćimović, R.; Simčič, J.; Pelicon, P.; Budnar, M.; Jeran, Z.; Pongrac, P.; Regvar, M.; et al. Application of X-ray fluorescence analytical techniques in phytoremediation and plant biology studies. Spectrochim. Acta Part $B$ At. Spectrosc. 2008, 63, 1240-1247. [CrossRef]

41. Zayed, A.; Gowthaman, S.; Terry, N. Phytoaccumulation of Trace Elements by Wetland Plants: I. Duckweed. J. Environ. Qual. 1998, 27, 715-721. [CrossRef]

42. Ter Braak, C.; Šmilauer, P. CANOCO Reference Manual and CanoDraw for Windows User's Guide: Software for Canonical Community Ordination (version 4.5). 2002. Available online: https://research.wur.nl/en/publications/canoco-referencemanual-and-canodraw-for-windows-users-guide-soft (accessed on 11 October 2021).

43. Bartoli, C.G.; Gomez, F.; Gergoff, G.; Guiamét, J.J.; Puntarulo, S. Up-regulation of the mitochondrial alternative oxidase pathway enhances photosynthetic electron transport under drought conditions. J. Exp. Bot. 2005, 56, 1269-1276. [CrossRef] [PubMed]

44. Germ, M.; Kreft, I.; Osvald, J. Influence of UV-B exclusion and selenium treatment on photochemical efficiency of photosystem II, yield and respiratory potential in pumpkins (Cucurbita pepo L.). Plant Physiol. Biochem. 2005, 43, 445-448. [CrossRef]

45. Smrkolj, P.; Germ, M.; Kreft, I.; Stibilj, V. Respiratory potential and Se compounds in pea (Pisum sativum L.) plants grown from Se-enriched seeds. J. Exp. Bot. 2006, 57, 3595-3600. [CrossRef]

46. Terry, N.; Zayed, A.M.; de Souza, M.P.; Tarun, A.S. Selenium in higher plants. Annu. Rev. Plant Biol. 2000, 51, 401-432. [CrossRef] [PubMed]

47. Mechora, Š.; Germ, M. Selenium induced lower respiratory potential in Glycine max (L.) Merr. Acta Agric. Slov. 2010, 95, 29-34. [CrossRef]

48. White, P.J. Selenium metabolism in plants. Biochim. et Biophys. Acta (BBA) Gen. Subj. 2018, 1862, 2333-2342. [CrossRef] [PubMed] 
49. Tarrahi, R.; Khataee, A.; Movafeghi, A.; Rezanejad, F.; Gohari, G. Toxicological implications of selenium nanoparticles with different coatings along with Se 4+ on Lemna minor. Chemosphere 2017, 181, 655-665. [CrossRef]

50. Akbulut, M.; Çakır, S. The effects of Se phytotoxicity on the antioxidant systems of leaf tissues in barley (Hordeum vulgare L.) seedlings. Plant Physiol. Biochem. 2010, 48, 160-166. [CrossRef] [PubMed]

51. Vítová, M.; Bišová, K.; Hlavová, M.; Zachleder, V.; Rucki, M.; Č́žková, M. Glutathione peroxidase activity in the selenium-treated alga Scenedesmus quadricauda. Aquat. Toxicol. 2011, 102, 87-94. [CrossRef]

52. Šircelj, H. Karotenoidi v Fotosinteznem Aparatu in Odziv na Stres. 2008. Available online: https://repozitorij.uni-lj.si/ IzpisGradiva.php?id=17642\&lang=eng (accessed on 15 October 2021).

53. Hawrylak-Nowak, B. Changes in Anthocyanin Content as Indicator of Maize Sensitivity to Selenium. J. Plant Nutr. 2008, 31, 1232-1242. [CrossRef]

54. Charron, C.S.; A Kopsell, D.; Randle, W.M.; E Sams, C. Sodium selenate fertilisation increases selenium accumulation and decreases glucosinolate concentration in rapid-cyclingBrassica oleracea. J. Sci. Food Agric. 2001, 81, 962-966. [CrossRef]

55. Sharma, P.; Dubey, R.S. Lead toxicity in plants. Braz. J. Plant Physiol. 2005, 17, 35-52. [CrossRef]

56. Besser, J.M.; Huckins, J.N.; Little, E.E.; La Point, T.W. Distribution and bioaccumulation of selenium in aquatic microcosms. Environ. Pollut. 1989, 62, 1-12. [CrossRef]

57. Kacjan Maršič, N.; Golob, A.; Šircelj, H.; Mihorič, M.; Kroflič, A.; Stibilj, V.; Germ, M. Effects of Exogenous Selenium in Different Concentrations and Forms on Selenium Accumulation and Growth of Spinach (Spinacia oleracea L.). J. Agric. Sci. Technol 2019, 21, 1905-1917.

58. Thor, K. Calcium-Nutrient and Messenger. Front. Plant Sci. 2019, 10. [CrossRef] [PubMed]

59. Xu, X.; Du, X.; Wang, F.; Sha, J.; Chen, Q.; Tian, G.; Zhu, Z.; Ge, S.; Jiang, Y. Effects of Potassium Levels on Plant Growth, Accumulation and Distribution of Carbon, and Nitrate Metabolism in Apple Dwarf Rootstock Seedlings. Front. Plant Sci. 2020, 11, 904. [CrossRef] [PubMed]

60. Keppeler, E.C. Toxicity of sodium chloride and methyl parathion on the macrophyte Lemna minor (Linnaeus, 1753) with respect to frond number and chlorophyll. Biotemas 2011, 22, 27-33. [CrossRef]

61. Forni, C.; Braglia, R.; Harren, F.; Cristescu, S. Stress responses of duckweed (Lemna minor L.) and water velvet (Azolla filiculoides Lam.) to anionic surfactant sodium-dodecyl-sulphate (SDS). Aquat. Toxicol. 2012, 110-111, 107-113. [CrossRef]

62. Liu, C.; Gu, W.; Dai, Z.; Li, J.; Jiang, H.; Zhang, Q. Boron accumulation by Lemna minor L. under salt stress. Sci. Rep. 2018, 8, 1-6. [CrossRef] [PubMed]

63. He, Y.; Xiang, Y.; Zhou, Y.; Yang, Y.; Zhang, J.; Huang, H.; Shang, C.; Luo, L.; Gao, J.; Tang, L. Selenium contamination, consequences and remediation techniques in water and soils: A review. Environ. Res. 2018, 164, 288-301. [CrossRef] 